\title{
Systematic Assessment for Quality Assurance in Management Education
}

\author{
Dr.D.Kavitha \\ Assistant Professor, Peelamedu \\ Coimbatore - 641004, Tamil Nadu, India \\ kavitha@psgim.ac.in
}

\author{
Dr.R.Sujatha \\ Assistant Professor, Peelamedu \\ Coimbatore - 641004, Tamil Nadu, India \\ sujatha@psgim.ac.in
}

\begin{abstract}
The system of education has undergone numerous transformations for centuries. Today, the emphasis of educational institutions is on quality. Though quality is an abstract term, a systematic assessment mechanism ensures effectiveness and helps in diagnosing the strengths and weaknesses of the teaching learning process. This paper provides a systematic framework for assessment that can be followed in institutions offering management education. The framework comprises of five steps that starts with establishing the programme learning goals and curriculum mapping. The execution phase of the assessment mechanism requires identification of appropriate assessment activities and its implementation followed by organizing and analyzing the assessment data. The final step of 'feedback and improvement' identifies tangible actions that are required to improve student learning.
\end{abstract}

Keywords: Quality Assurance, Assessment, Management Education, Goals, Outcomes.

\section{INTRODUCTION}

Management education has a vital role to play in today's business environment. It is an indicator of a nation's ability to participate in world science and the global economy (Hazelkorn, 2015). Countries with a strong and efficient education system have driven the transformation of some economies that were just 'cheaper labour sources' to those of innovative higher valued products and services (Cheese et al., 2007). To achieve this, educational institutions are compelled to offer quality education that is at par with global standards.

Quality can be assured through multitude internal and external mechanisms. These mechanisms are based on the principles of accountability, control and improvement (Harvey, 1998). A large number of these mechanisms focus on curriculum design, delivery, assessment and overall learning which lead to creating students with industry relevant skills, a broad knowledge base and a set of competencies that are required to enter the complex and interdependent world (Altbach et al., 2009).

Assessment of learning has evolved as a major factor in quality assurance. The effectiveness of the teaching-learning process is made evident through the assessment process and results (Nandagopal et al., 2012). A well planned and executed assessment process aids to obtain information on the effectiveness of the learning environment and to diagnose strengths and weaknesses leading to remedial action (Atkins, 1993). To ensure quality in the teaching-learning process educational institutions need to have a robust assessment system. The purpose of this paper is to present a systematic framework for assessing the learning outcomes of a management programme. The structure of this paper is as follows. Section 2 presents a review of relevant literature. Section 3 presents the assessment framework. Section 4 gives an example for systematic assessment. The final section presents the conclusion.

\section{REVIEW OF LITERATURE}

Educational institutions are moving from a system of trust to a system of evidence (Garrett et al., 2012). This has led to increasing research in the domain of assessment and quality assurance. The system of quality assurance is continous and integrative, and facilitates institutions to remain proactive, avoid failures and improve the delivery of services (Warren et.al., 1994). Quality is abstract and hence each stakeholder has a different perspective (Harvey and Green, 1993). In educational research, quality has been equated to various dimensions such as Excellence (Moodie, 
1988), Exceptionality, Fitness for purpose, Transformation (Ruben, 1995), Enhancement, Perfection or Value for money (Harvey and Green, 1993; Parri J, 2006).

A study by Harvey (1999) indicated that quality assurance in higher education is based on the principles on Accountability, Control and Improvement. The principle of accountability ensures that the quality assurance process meets the demands of the institute's internal and external stakeholders. The principle of control ensures that the institution provides 'value for money'. The last principle, improvement aids to continuously improve the standards of input, process and output of the institution so that it meets the stated goals.

Systematic assessment is one of the accepted mechanisms to ensure quality in education (Marshall, 2007; Pringle and Michel, 2007; Pesta and Scherer, 2011). Assessment is defined as the systematic collection, review and use of information about educational programmes undertaken for the purpose of improving learning and development (Palomba and Banta, 1999). A good assessment process has to be consistent with an institution's mission (Beard, Schwieger, and Surendran, 2008) and should add to the credibility and continuous improvement efforts. Assessment makes the educator more accountable in creating learning experiences and achieving significant outcomes. It is formally defined as a measure of performance (Gagne et. al., 2005). A formal assessment process involves externally valid record sets, multiple years of data and a continuous improvement process (Julian and Ofori-Dankwa, 2006). The agents of assessment i.e., the faculty / teacher also determine the rigor and validity of the assessments.

'Why' the assessment is done is more important than 'what' is being assessed and 'how' it is being assessed (Brown 2005). Atkins (1993) in her study has identified numerous reasons for assessing students. One of the major reasons is to establish progress during a course and at the end of the course to provide feedback. The other reasons highlighted were, to determine the extent to which course goals have been achieved, to obtain information on the effectiveness of the learning environment and to diagnose strengths and weaknesses leading to remedial action.

Research has proven and documented the positive impact of assessment on programme learning outcomes (Stiggins, 2002; Black and Wiliam, 1998) and student learning outcomes (Black et al., 2004). The result of the outcomes assessment provides inputs to the feedback loop to be used by faculty to improve the teaching-learning process.

\section{ASSESSMENT FRAMEWORK}

An effective assessment model typically consists of a series of steps that needs to be implemented in sequence. However, improvements are possible at any stage of the framework. This assessment framework was developed based on the review of literature and is presented in Figure 1. The framework is in accordance to the requirements of several national and international accreditation bodies.

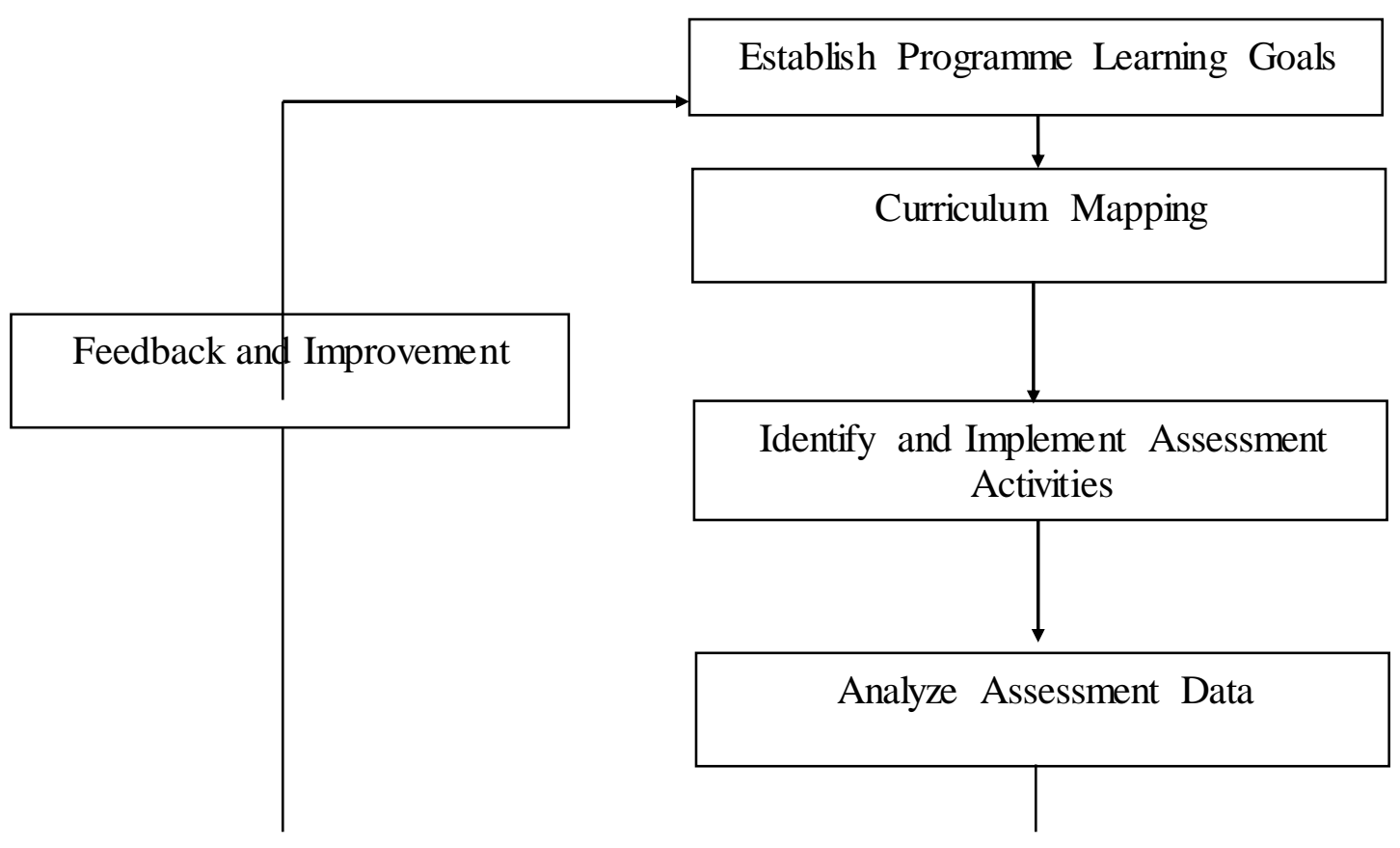


Figure1. Systematic Assessment Framework

\subsection{Establish Programme Learning Goals}

Learning goals refer to the overarching purpose of the curriculum (Marzano, 2015). Each educational institution will have a basic purpose of existence that is reflected in its mission and vision statements. These provide directions for developing learning goals of various prgrammes offered by the institution. The development of the programme learning goals should involve all the stakeholders such as faculty, management, students, alumni, industry etc., (Gardiner et al., 2010). A well constructed goal should contain a clear reference to a specific type of knowledge that demonstrate proficiency (Tyler, 1949). The learning goals can be a combination of mastery goals and performance goals. While mastery goals focus on competencies, performance goals specify a score or grade to be obtained by students and express the achievement of the mastery goals (Marzano, 2015). The goals should be reviewed periodically and improved continuously (Gardiner et al., 2010). The learning goals of a management programme can focus on analytical skills, decision-making skills, communication skills, entrepreneurial qualities, leadership ability, global perspective, ethics etc. These goals are generic and therefore should be broken down into specific outcomes that are measurable, which are commonly referred to as student learning outcomes.

For e.g., if the programme learning goal is "to demonstrate entrepreneurial and leadership qualities", the student learning outcomes could be:

- Ability to scan the environment for new opportunities and constraints

- Exhibit leadership abilities

- Exhibit team playing abilities

\subsection{Curriculum Mapping}

Curriculum mapping provides a means to examine the extent to which the programme learning goals are being addressed and assessed in the curriculum. The curriculum map provides the list of courses offered in the programme and the goals that can be assessed. This process will help in identifying if the curriculum provides an opportunity to measure the goals intended to be delivered in the programme. If a gap is present i.e. there are no courses to measure a learning goal, it is essential to review the curriculum of the programme and modify it so that the learning goal is measureable. A sample curriculum map is presented in Table 1 .

Table1. Curriculum Map

\begin{tabular}{|l|l|l|l|l|l|}
\hline $\begin{array}{l}\text { Courses } \backslash \\
\text { Programme } \\
\text { Learning Goals }\end{array}$ & $\begin{array}{l}\text { Programme } \\
\text { Learning } \\
\text { Goal 1 }\end{array}$ & $\begin{array}{l}\text { Programme } \\
\text { Learning } \\
\text { Goal 2 }\end{array}$ & $\begin{array}{l}\text { Programme } \\
\text { Learning } \\
\text { Goal 3 }\end{array}$ & $\begin{array}{l}\text { Programme } \\
\text { Learning } \\
\text { Goal 4 }\end{array}$ & $\begin{array}{l}\text { Programme } \\
\text { Learning } \\
\text { Goal 5 }\end{array}$ \\
\hline Course 1 & & $\sqrt{ }$ & & $\sqrt{ }$ & \\
\hline Course 2 & $\sqrt{ }$ & & & $\sqrt{ }$ & \\
\hline Course 3 & $\sqrt{ }$ & & & & \\
\hline
\end{tabular}

\subsection{Identify and Implement Assess ment Activities}

This step consists of activities that answer the following questions:

- How to assess?

- When to assess?

- Who to assess?

- Who does the assessment? (Gardiner et al., 2010).

\section{How to assess?}

Assessment can be performed using multiple measures. They can be Direct Measures or Indirect Measures. Direct measures include assessments that are performed on the students currently pursuing the course. It could be in the form of course embedded assessment or external assessment. Direct measures provide evidence about student learning and the learning environment through exams, 
projects, role plays, case studies, group discussions etc. Indirect assessment provides evidence about the students' experience about learning through surveys, questionnaires, interviews etc. Exit surveys, survey among alumni, feedback from industry recruiters etc are the most popular methods of indirect assessment.

\section{When to Assess?}

A time-line for assessing the programme learning goals should be defined. The assessment of all the goals may not be possible each year. The cycle would therefore consist of assessment of few goals in the first year, few in the second and so on. The final assessment data can be consolidated only on completion of the assessment cycle. A sample of the time-line is provided in Table 2.

Table2. Time-line for Assessment

\begin{tabular}{|c|c|c|c|c|c|}
\hline Year & Year 1 & Year 2 & Year 3 & Year 4 & Year 5 \\
\hline $\begin{array}{lll}\text { Programme } & \text { Learning } & \text { Goals } \\
\text { Assessed } & & \\
\end{array}$ & $\begin{array}{l}\text { For eg. } \\
\text { Goal 1, } \\
\text { Goal } 2\end{array}$ & $\begin{array}{lr}\text { For } & \text { eg. } \\
\text { Goal } & 3, \\
\text { Goal } & 4\end{array}$ & $\begin{array}{l}\text { For eg. } \\
\text { Goal } 5\end{array}$ & $\begin{array}{lr}\text { For } & \text { eg. } \\
\text { Goal } & 1, \\
\text { Goal } & 3\end{array}$ & $\begin{array}{lr}\text { For eg. } \\
\text { Goal } & 4, \\
\text { Goal } & 5\end{array}$ \\
\hline $\begin{array}{l}\text { Direct Measures / Indirect } \\
\text { Measures Used for Assessment }\end{array}$ & & & & & \\
\hline
\end{tabular}

Who to Assess?

Assessment of the programme learning goals can be done either on a sample of students or on the full student population. As some of the assessments are time-consuming, it is preferable to use a sample of students for such measures. However, it is crucial to decide this before the start of any assessment cycle.

\section{Who does the Assessment?}

The course-embedded assessments are generally done by the faculty or by an assessment team constituted specifically for this purpose. Standardized assessment tests by external agencies are also available. Most of these provide measures of achievement of the mastery goals. Assessments by the faculty at the course-level are required to augment these results to demonstrate the achievement of performance goals.

\subsection{Analyze Assessment Data}

After the collection of assessment data, the faculty team or the assessment team should compile and organize the data in accordance to the goals. Analysis requires appropriate targets to be set for each learning goal. The targets are usually fixed by the faculty team in concurrence with the assessment team. An example is provided in Table 3.

Table3. Execution of Assessment

\begin{tabular}{|l|l|l|l|l|}
\hline $\begin{array}{l}\text { Programme } \\
\text { Learning } \\
\text { Goal }\end{array}$ & $\begin{array}{l}\text { Student } \\
\text { Learning } \\
\text { Outcome }\end{array}$ & Target & Assessments & Results \\
\hline $\begin{array}{l}\text { To } \\
\text { demonstrate } \\
\text { entrepreneurial } \\
\text { and leadership } \\
\text { qualities }\end{array}$ & $\begin{array}{l}\text { Exhibit } \\
\text { leadership } \\
\text { abilities }\end{array}$ & $\begin{array}{l}70 \% \text { of the students } \\
\text { should be able to } \\
\text { achieve 'good' or } \\
\text { 'excellent' levels in } \\
\text { the respective } \\
\text { assessments }\end{array}$ & $\begin{array}{l}\text { Course Embedded Assessments - Case } \\
\text { Analysis and Role Play in the course - } \\
\text { Indirect Measures-Relevant Questions } \\
\text { in Students' Exit Survey }\end{array}$ & $\begin{array}{l}\text { Only } 60 \% \text { of } \\
\text { the students } \\
\text { achieved } \\
\text { 'good' } \\
\text { 'excellent' } \\
\text { or }\end{array}$ \\
\hline
\end{tabular}

The assessment data is compared with the set targets to ascertain the achievement of the goal. If the target is accomplished, it indicates that the curriculum design and delivery of the programme is satisfactory. However, if the target is not reached, it indicates a gap in the process and helps in identifying areas for improvement in the curriculum design and delivery process. In the example provided in Table 4, the target was not achieved and indicates that improvements are required in the course.

\subsection{Feedback and Improvement}

This is the final step in the assessment process. In the post-analysis phase faculty are required to review the data and suggest possible improvements in the respective courses. This would result in a set of actions that require screening in terms of feasibility, cost, time and other resources required 
(Gardiner et al., 2010). These improvements could range from course-level changes to changes at the programme-level such as improving admission requirements, academic advising, mentoring, tutoring, academic support etc. The time-frame of implementing the suggested changes should also be specified. If the improvements can be incorporated within a short span of time, a reassessment of the goal could be done within the same assessment cycle.

\section{Systematic AsSessment EXAMPLE}

Programme Learning Goal: To demonstrate entrepreneurial and leadership qualities

Student Learning Outcome: Exhibit leadership abilities

Assessment of this Outcome: This outcome was assessed directly in two courses, Organizational Behavior and Human Resource Management.

Target Set: It was decided that at least $70 \%$ of the students should be able to achieve 'good' or 'excellent' levels in the above said courses.

Performance: The leadership skills of the students were assessed using case studies. The performance of the students was evaluated individually. As is evident from the Figure 2 and Figure 3 given below, $75.5 \% *$ of the students have scored 'good' or 'excellent' in exhibiting their leadership skills.

*Average of Organizational Behavior (72\%) and Human Resource Management (79\%)

Feedback and Improvement: Although the set target was achieved, in order to further improve the performance of the students in the 'fair' level, activities which exhibit and enhance the leadership and team building skills will be conducted.

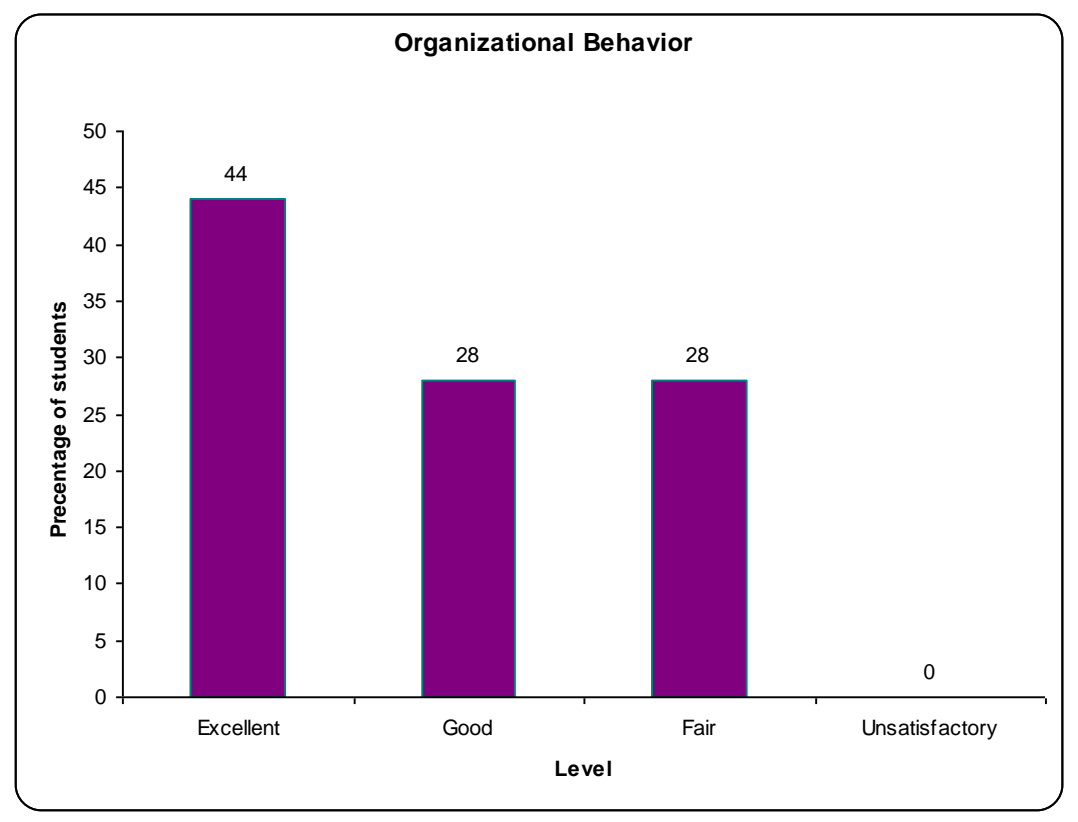

Figure2. Assessment of Leadership Skills in Course 1 


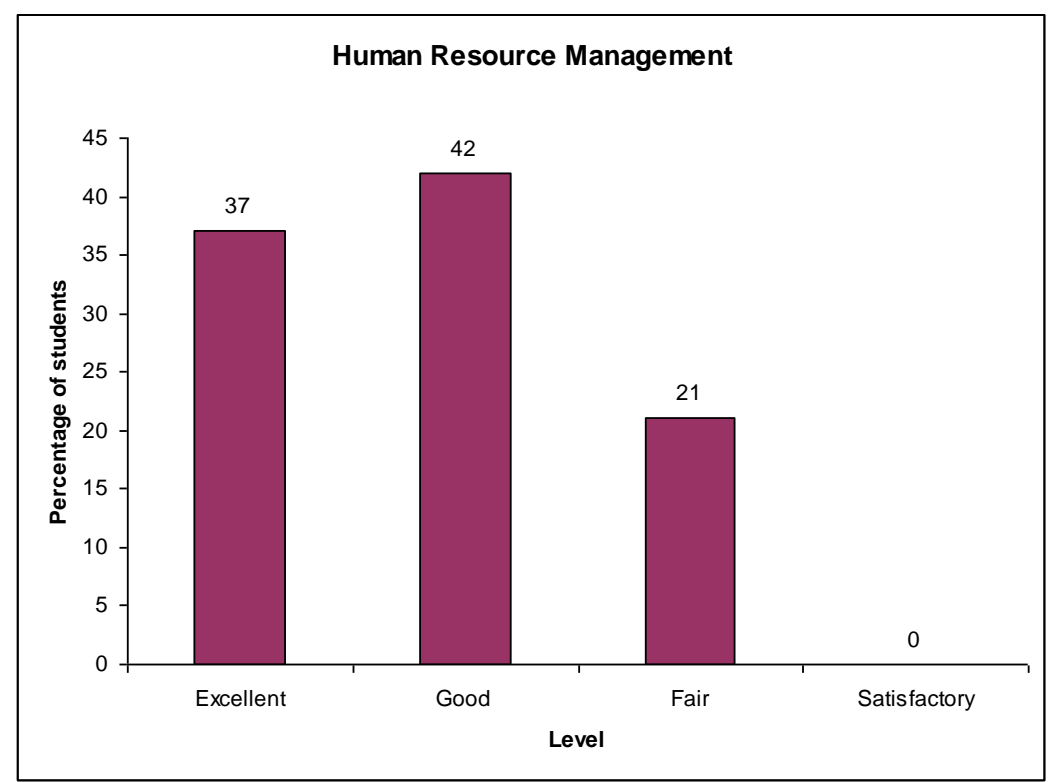

Figure3. Assessment of Leadership Skills in Course 2

\section{CONClusion}

It is essential for educational institutions, particularly those of higher learning to demonstrate quality and its achievement in the programmes. The process of assessment presents various challenges to the educational institutions. A systematic assessment process will help in overcoming these challenges and create an environment for continuous improvement. The assessment process provides output to various stakeholder groups about the level of student performance. The assessment process indicates the extent to which the programme learning goals and objectives have been met and highlights the changes that are required in the curriculum design and delivery process. This paper presented an achievable five step process of assessment which all institutions can follow to ensure quality. Assessment is a time consuming process and its success requires commitment from the faculty and adequate supporting resources from the educational institutions.

\section{REFERENCES}

[1] Altbach, P, G., Reisberg, L. and Rumbley, L.E. Trends in Global Higher Education : Tracking an Academic Revolution, A Report Prepared for the UNESCO 2009 World Conference on Higher Education, available at http:/unesdoc.unesco.org/images/0018/001831/183168e.pdf (accessed February 27, 2016)

[2] Atkins, M. J. (1993). Assessment issues in Higher Education, available at: http://eric.ed.gov/PDFS/ED369370.pdf

[3] Beard, D., Schwieger, D., and Surendran, K. (2008). Preparing the millennial generation for the work place: how can academia help?. In Proceedings of the 2008 ACM SIGMIS CPR conference on Computer personnel doctoral consortium and research, pp. 102-105.

[4] Black, P., \& Wiliam, D. (1998). Assessment and classroom learning. Assessment in education, 5(1), pp. 7-74.

[5] Black, P., Harrison, C., \& Lee, C. (2004). Working inside the black box: Assessment for learning in the classroom. Granada Learning.

[6] Brown S, (2005). Assessment for Learning, Learning and Teaching in Higher Education, 1(1), pp. 81-89.

[7] Cheese, P., Thomas, R. J., and Craig, E. (2008). The talent powered organization. UK: Kogan Page.

[8] Gagne, R.M., Wager W.W., Golas K.C. and Keller J.M. (2005). Principles of Instructional Design, Thomson Wadsworth, U.S.A.

[9] Gardiner, L. R., Corbitt, G., \& Adams, S. J. (2009). Program assessment: Getting to a practical how-to model. Journal of Education for Business, 85(3), pp. 139-144. 
[10] Harvey, L. (1998). An Assessment of Past and Current Approaches to Quality in Higher Education", Australian Journal of Education, 42(3), pp. 237-255.

[11] Harvey, L., and Green, D. (1993). Defining quality. Assessment \& evaluation in higher education, 18(1), pp. 9-34.

[12] Hazelkorn, E. (2015). Rankings and the reshaping of higher education: The battle for world-class excellence. Palgrave Macmillan.

[13] Julian, S. D., and Ofori-Dankwa, J. C. (2006). Is accreditation good for the strategic decision making of traditional business schools?. Academy of Management Learning \& Education, 5(2), pp. 225-233.

[14] Marshall, L. (2007). Measuring assurance of learning at the degree program and academic major levels, Journal of Education for Business, 83(2), pp. 101-109.

[15] Marzano, R. J. (2015). Designing \& teaching learning goals \& objectives. Solution Tree Press.

[16] Moodie, G. C. (1988). The Debates about Higher Education Quality in Britain and in the USA, Studies in Higher Education, Vol. 13, pp. 5-13.

[17] Nandagopal, R., Sujatha, R., Kavitha, D. (2012). Development and Deployment of Rubrics as an Assessment Tool for Grading Cases - The Experience of an Indian Business School, Achieving Excellence Through Accreditation (Eds), Bloomsbury Publishing India Pvt. Ltd. New Delhi.

[18] Palomba, C.A. and Banta, T.W. (1999). Assessment Essentials: Planning, Implementing, and Improving Assessment in Higher Education, Jossey-Bass, San Francisco

[19] Parri, J. (2006). Quality in Higher Education, Vadyba / Management, Vol. 2, No. 11, pp 107111.

[20] Pesta, B.J. and Scherer, R.F. (2011). The assurance of learning tool as predictor and criterion in business school admissions decisions: new use for an old standard?, Journal of Education for Business, 86(3), pp. 163-170.

[21] Pringle, C., \& Michel, M. (2007). Assessment practices in AACSB accredited business schools. Journal of Education for Business, 82(4) , pp. 202-211.

[22] Ruben, B. D. (1995). Quality in higher education. Transaction Publishers.

[23] Stiggins, R. J. (2002). Assessment crisis: The absence of assessment for learning. Phi Delta Kappan, 83(10), pp. 758.

[24] Tyler, R. W. (1949). Achievement testing and curriculum construction. Trends in student personnel work, 3914107.

[25] Warren, J., McManus, K. and Nnazor, R. (1994). Quality Assurance and Distance Education: A Review of the Literature, Deshpande, P. M.and Mugridge, I. (eds.), Quality Assurance in Higher Education: Papers presented to a symposium on quality assurance, Vancouver: The Commonwealth of Learning, New Delhi.

\section{AUTHORS' BIOGRAPHY}

Dr. D. Kavitha, is a graduate in Commerce and post-graduate in Management from Bharathiar University. She has an excellent academic track record with University Ranks in both her degrees. She received her Doctorate from Anna University for her thesis titled "A Study on the Effect of Corporate Governance Mechanisms on the Discretionary Disclosures of Indian Firms". She currently teaches Accounting and Corporate Social Responsibility. She has trained at the Harvard Business School in the case teaching pedagogy and innovation in teaching and course design.

Dr.R.Sujatha, is an Assistant Professor at PSG Institute of Management, PSG College of Technology. Her Ph.D. is in the area of Capacity Building and Knowledge Management from Anna University, Chennai. She has published papers in national and international journals on topics related to Supply Chain Management and Knowledge Management. She has been instrumental in installing Learning Management Software. She undertakes consultancy projects for deployment and training of Learning Management System and ERP software. She has visited Texas Christian University, San Diego State University, University of Toledo and Claflin University, USA as part of Faculty Exchange Program to understand curriculum design and delivery process. 